\title{
Article
}

\section{MIL-53 (Al) derived single-atom Rh catalyst for the selective hydrogenation of $\boldsymbol{m}$-chloronitrobenzene into $\boldsymbol{m}$-chloroaniline}

\author{
Weiyin Wang a,b, $\dagger$, Lu Lin b, ${ }^{b}$, Haifeng Qi b,c, Wenxiu Cao d, Zhi Li ${ }^{e}$, Shaohua Chen ${ }^{\mathrm{f}}$, Xiaoxuan Zou a,\#, \\ Tiehong Chen ${ }^{\mathrm{f}}$, Nanfang Tang ${ }^{\mathrm{b}}$, Weiyu Song $\mathrm{e}$, Aiqin Wang b,g, Wenhao Luo ${ }^{\mathrm{b}, *}$ \\ a College of Chemistry, Xiangtan University, Xiangtan 411105, Hunan, China \\ b CAS Key Laboratory of Science and Technology on Applied Catalysis, Dalian Institute of Chemical Physics, Chinese Academy of Sciences, Dalian 116023, \\ Liaoning, China \\ c University of Chinese Academy of Sciences, Beijing 100049, China \\ d College of Chemistry and Chemical Engineering, Jishou University, Jishou 416000, Hunan, China \\ e State Key Laboratory of Heavy Oil Processing, China University of Petroleum, Beijing 102249, China \\ ${ }_{\mathrm{f}}^{\mathrm{f}}$ Institute of New Catalytic Materials Science, School of Materials Science and Engineering, Key Laboratory of Advanced Energy Materials Chemistry \\ (MOE), Nankai University, Tianjin 300350, China \\ g State Key Laboratory of Catalysis, Dalian Institute of Chemical Physics, Chinese Academy of Sciences, Dalian 116023, Liaoning, China
}

\section{A R T I C L E I N F O}

\section{Article history:}

Received 8 May 2020

Accepted 7 July 2020

Available online 22 September 2020

\section{Keywords:}

Single-atom catalyst

Rhodium

Metal-organic framework

Hydrogenation

Chemoselectivity

\section{A B S T R A C T}

The catalytic hydrogenation of halonitroarenes to haloanilines is a green and sustainable process for the production of key nitrogen-containing intermediates in fine chemical industry. Chemoselective hydrogenation poses a significant challenge, which requires the rational design of the catalysts with proper hydrogenation ability for nitro group and simultaneously preventing dehalogenation of halogen group. Herein, a highly effective $\mathrm{Rh} @ \mathrm{Al}_{2} \mathrm{O}_{3} @ \mathrm{C}$ single-atom catalyst (SAC) was developed for the hydrogenation of $m$-chloronitrobenzene $(m$-CNB) to $m$-chloroaniline ( $m$-CAN), through an in-situ grafting of metal during the assembly of MIL-53 (Al), followed by confined pyrolysis. Extensive characterizations reveal an exquisite structure of the $\mathrm{Rh} @ \mathrm{Al}_{2} \mathrm{O}_{3} @ \mathrm{C}$, containing atomically dispersed $\mathrm{Rh}$ sites onto $\mathrm{Al}_{2} \mathrm{O}_{3}$ confined by the amorphous carbon. The five-coordinated aluminum ( $\mathrm{Al}^{\mathrm{V}}$ ) species are essential for achieving the atomic dispersion of $\mathrm{Rh}$ atoms, providing the unsaturated coordinative sites for metal. Compared to the benchmark $\mathrm{Rh} / \gamma-\mathrm{Al}_{2} \mathrm{O}_{3}$ and $\mathrm{Rh} / \mathrm{C}$ nanocatalysts, the $\mathrm{Rh} @ \mathrm{Al}_{2} \mathrm{O}_{3} @ \mathrm{C}$ SAC affords an excellent turnover frequency of $2317 \mathrm{~mol}_{\mathrm{m}-\mathrm{CNB}} \cdot \mathrm{mol}_{\mathrm{Rh}^{-1}} \cdot \mathrm{h}^{-1}$, the highest value to date in heterogeneous catalyst systems for the hydrogenation of $m$-CNB at $313 \mathrm{~K}$ and 20 bar $\mathrm{H}_{2}$, together with a sustained selectivity to $m$-CAN ( 98\%) during five consecutive runs. The superior catalytic performance of the $\mathrm{Rh} @ \mathrm{Al}_{2} \mathrm{O}_{3} @ \mathrm{C}$ is attributed to a proper modulation of electronic structure of hydrogenation metal by forming SAC, together with an enhanced accessibility of acid function sites.

(C) 2021, Dalian Institute of Chemical Physics, Chinese Academy of Sciences. Published by Elsevier B.V. All rights reserved.

\footnotetext{
* Corresponding author. Tel: +86-411-84379738; Fax: +86-411-84685940; E-mail: w.luo@dicp.ac.cn

\# Corresponding author. E-mail: zouxiaoxuan@xtu.edu.cn

† Contributed equally to this work.

This work was supported by the Strategic Priority Research Program of the Chinese Academy of Sciences (XDB17020100), the National Natural Science Foundation of China (21703238, 21690084, 21802134), Educational Commission of Hunan Province (19B463), Collaborative Innovation Center of Manganese-Zinc-Vanadium Industrial Technology (MXF202001), and Research Startup Foundation of Jishou University (No.21). DOI: 10.1016/S1872-2067(20)63697-X | http://www.sciencedirect.com/science/journal/18722067 | Chin. J. Catal., Vol. 42, No. 5, May 2021
} 


\section{Introduction}

Haloanilines are important and valuable intermediates for the manufacture of many pharmaceuticals, polymers, dyes, and agrochemicals [1-3]. Commercial production of haloanilines generally applies metallic iron to reduce the related nitroarenes in acidic media, which is costly and environmentally unfriendly [4]. Recently, catalytic hydrogenation of halonitroarenes with heterogeneous metal catalysts has emerged as an effective, green and sustainable process for the production of haloanilines [5-8]. Still, the difficulty in selectively reducing the nitro group arises from the presence of the other reducible halogen groups, which often results in a decrease in selectivity at high conversions of halonitroarenes [9]. Attempts with adding a second substance (i.e. amines, thiophene, etc.) as inhibitors or modifying agents to reaction medium, were made for suppressing the side reactions, however, it brings new issues related to isolation and purification of the final products, resulting in such approach economically less viable [10-12]. Therefore, the rational design of heterogeneous catalysts for the selective hydrogenation of halonitroarenes into haloanilines, is still highly desirable but challenging.

Intensive research efforts have been devoted to the development of efficient heterogeneous catalysts [13-17]. Notably, Xiao et al. [18] successfully prepared a Pd@Beta via the fixation of Pd nanoparticles inside Beta zeolite crystals, which achieved a high selectivity of $m$-bromoaniline ( $>99 \%$ ) by controlling the steric adsorption of nitro groups on Pd nanoparticles, for the chemoselective hydrogenation of the $m$-bromonitrobenzene at $383 \mathrm{~K}$ and 10 bar $\mathrm{H}_{2}$. Cárdenas-Lizana and coworkers [19] reported a highly effective bimetallic $\mathrm{Pd}-\mathrm{Au} / \mathrm{Al}_{2} \mathrm{O}_{3}$ catalyst $(>99 \%$ selectivity to $p$-chloroaniline) for the selective hydrogenation of p-chloronitrobenzene at $393 \mathrm{~K}$ and $10 \mathrm{bar}_{2}$, by alloying $\mathrm{Au}$ with Pd to modulate the hydrogenation activity of metal sites. Recently, single-atom catalysts (SACs) approaches, owing to the increased uniformity and well-defined active sites, have emerged as a promising class of catalyst materials for the selective hydrogenation of halonitroarenes to haloanilines [20-23]. For example, a $\mathrm{Pt} / \mathrm{FeO}_{\mathrm{x}} \mathrm{SAC}$ afforded a $97.4 \%$ selectivity to $o$-chloroaniline under mild conditions $\left(T=313 \mathrm{~K}, P_{\mathrm{H} 2}=3 \mathrm{bar}\right)$ [24]. Another $\mathrm{Pt} / \mathrm{CeO}_{2} \mathrm{SAC}$ could sustain $99.5 \%$ selectivity to

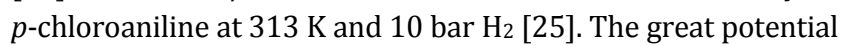
of SACs for such selective hydrogenation to haloaniline is possibly due to the nature of their positively charged chemical state, enabling a proper modulation of the hydrogenation ability to fulfill the optimization of the catalytic properties $[20,26,27]$.

In this contribution, we have prepared a highly efficient $\mathrm{Rh} @ \mathrm{Al}_{2} \mathrm{O}_{3} @ \mathrm{C} \mathrm{SAC}$, via an in-situ synthesis approach during the assembly of MIL-53 (Al), followed by confined pyrolysis. Combined characterizations of aberration corrected high angle annular dark field mode of scanning transmission electron microscopy (AC-HAADF-STEM) and infrared spectroscopy using $\mathrm{CO}$ as the probe molecule (IR-CO) reveal an exquisite structure of the $\mathrm{Rh} @ \mathrm{Al}_{2} \mathrm{O}_{3} @ \mathrm{C}$, containing atomically dispersed Rh sites onto $\mathrm{Al}_{2} \mathrm{O}_{3}$ confined by the amorphous carbon. The presence of five-coordinated aluminum ( $\mathrm{Al}$ ) species, is demonstrated to be essential for achieving atomically dispersion of $\mathrm{Rh}$ sites in the $\mathrm{Rh} @ \mathrm{Al}_{2} \mathrm{O}_{3} @ \mathrm{C}$ through ${ }^{27} \mathrm{Al}$ magic angle spinning nuclear magnetic resonance (27Al MAS NMR) and DFT calculation. The obtained $\mathrm{Rh} @ \mathrm{Al}_{2} \mathrm{O}_{3} @ \mathrm{C}$ SAC has been tested and compared with the benchmark $\mathrm{Rh} / \mathrm{C}$ and $\mathrm{Rh} / \gamma-\mathrm{Al}_{2} \mathrm{O}_{3}$ nanocatalysts for the hydrogenation of $m$-chloronitrobenzene $(m$-CNB) into $m$-chloroaniline ( $m$-CAN). The $\mathrm{Rh} @ \mathrm{Al}_{2} \mathrm{O}_{3} @ \mathrm{C}$ SAC affords an excellent activity (TOF $=2317 \mathrm{~mol}_{m \text {-CNB }} \cdot \mathrm{mol}_{\mathrm{Rh}^{-1}}{ }^{-1} \mathrm{~h}^{-1}$ ) and a sustained $m$-CAN selectivity ( $\sim 98 \%$ in five consecutive runs). Further characterization studies reveal that the superior catalytic performance of the SAC is attributed to a proper modulation of the electronic structure of hydrogenation metal, together with an enhanced accessibility of acid function sites. This work provides not only an effective strategy for the preparation of SACs via utilizing the metal-organic framework as scaffold, but also shows a prominent example on tuning the electronic structure of hydrogenation metal by forming SAC for an enhanced chemoselectivity in catalysis.

\section{Experimental}

\subsection{Synthesis of materials}

In a typical procedure, $\mathrm{Al}\left(\mathrm{NO}_{3}\right)_{3} \cdot 9 \mathrm{H}_{2} \mathrm{O}(5.2 \mathrm{~g}, 13.9 \mathrm{mmol}$, Tianjin Damao Chemical Reagent Factory, 99\%), terephthalic acid $\left(\mathrm{H}_{2} \mathrm{BDC}, 1.152 \mathrm{~g}, 6.9 \mathrm{mmol}\right.$, J\&K, 99\%) and $\mathrm{RhCl}_{3} \cdot 3 \mathrm{H}_{2} \mathrm{O}(8$ $\mathrm{mg}, 0.03 \mathrm{mmol}$, Tianjin Sailboat Chemical Reagent Technology Co., Ltd., 99\%) were dissolved in $\mathrm{H}_{2} \mathrm{O}(20 \mathrm{~mL})$ under ultrasonication for $0.5 \mathrm{~h}$. The mixture was then added into a $50 \mathrm{~mL}$ Teflon-lined stainless steel autoclave, heated to $493 \mathrm{~K}$ and kept for $72 \mathrm{~h}$. A white powder of Rh@MIL-53 (Al) was collected by filtration, washed three times with $\mathrm{H}_{2} \mathrm{O}$ and ethanol, and dried at 333 K overnight. The dried Rh@MIL-53 (Al) was first calcined at $873 \mathrm{~K}$ for $5 \mathrm{~h}$ with a heating rate of $5 \mathrm{~K} \cdot \mathrm{min}^{-1}$ in an Ar flow of $30 \mathrm{~mL} \cdot \mathrm{min}^{-1}$ and then reduced at $573 \mathrm{~K}$ for $3 \mathrm{~h}$ with a heating rate of $2 \mathrm{~K} \cdot \mathrm{min}^{-1}$ in a $10 \mathrm{vol} \% \mathrm{H}_{2} /$ Ar flow of $30 \mathrm{~mL} \cdot \mathrm{min}^{-1}$. After being cooled to room temperature, a black powder was obtained and denoted as $\mathrm{Rh} @ \mathrm{Al}_{2} \mathrm{O}_{3} @ \mathrm{C}$ material. The content of carbon in the $\mathrm{Rh} @ \mathrm{Al}_{2} \mathrm{O}_{3} @ \mathrm{C}$ is determined to be 36.5 wt $\%$ On the basis of thermogravimetric (TG) analysis results (Fig. S1, see electronic supporting information, the same below). The Rh

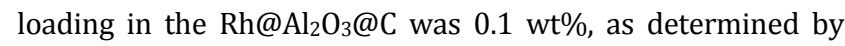
inductively coupled plasma optical emission spectroscopy (ICP-OES).

The $\mathrm{Rh} / \gamma-\mathrm{Al}_{2} \mathrm{O}_{3}$ catalyst was prepared via a wet impregnation method. $\gamma-\mathrm{Al}_{2} \mathrm{O}_{3}(1 \mathrm{~g}, 9.8 \mathrm{mmol}$, Aladdin, 99.99\%), $\mathrm{RhCl}_{3} \cdot 3 \mathrm{H}_{2} \mathrm{O}\left(1 \mathrm{mg}, 3.8 \times 10^{-3} \mathrm{mmol}\right.$, Tianjin Sailboat Chemical Reagent Technology Co., Ltd., 99\%) and $\mathrm{H}_{2} \mathrm{O}$ (2.130 mL) was first mixed at room temperature. After ultrasonication for 30 min, the slurry was stirred vigorously at room temperature for $12 \mathrm{~h}$, and then dried at $333 \mathrm{~K}$ overnight. The Rh loading in $\mathrm{Rh} / \gamma-\mathrm{Al}_{2} \mathrm{O}_{3}$ was $0.1 \mathrm{wt} \%$, as detected by ICP-OES.

The $\mathrm{Rh} / \mathrm{C}$ catalyst was prepared via a wet impregnation 
method. Activated charcoal (1 g, $83.3 \mathrm{mmol}$, Aladdin, AR), $\mathrm{RhCl}_{3} \cdot 3 \mathrm{H}_{2} \mathrm{O}\left(1 \mathrm{mg}, 3.8 \times 10^{-3} \mathrm{mmol}\right.$, Tianjin Sailboat Chemical Reagent Technology Co., Ltd., 99\%) and $\mathrm{H}_{2} \mathrm{O}$ (2.175 mL) was first mixed at room temperature. After ultrasonication for 30 $\mathrm{min}$, the slurry was stirred vigorously at room temperature for $12 \mathrm{~h}$, and then dried at $333 \mathrm{~K}$ overnight. The Rh loading in $\mathrm{Rh} / \mathrm{C}$ was $0.1 \mathrm{wt} \%$, as detected by ICP-OES.

\subsection{Catalyst characterizations}

Powder X-ray diffraction (PXRD) was carried out using the PW3040/60 X'Pert Pro powder X-ray diffractometer from PANAnalytical, the Netherlands. The diffraction source was $\mathrm{Cu}$ $K \alpha$ ray $(\lambda=1.5432 \AA)$, Ni filtered, LynxExe array detector, tube voltage and tube current were $40 \mathrm{KV}, 40 \mathrm{~mA}$, respectively. The scanning step is $0.02^{\circ}$. The crystalline phase was identified with reference to the ICDD PDF-2 database.

TG was studied on SETSYS 16/18 DSC 114 (SETARAM), and the heating rate is $10 \mathrm{~K} \cdot \mathrm{min}^{-1}$ under $10 \mathrm{bar}$ Air atmosphere.

The actual Rh loading of the rhodium catalyst was determined by ICP-OES on an IRIS Intrepid II XSP instrument (Thermo Electron Corporation) with a sensitivity line of 349.8 $\mathrm{nm}$ and a detection range of 1-10 ppm.

$\mathrm{N}_{2}$ physisorption isotherms were obtained at $77 \mathrm{~K}$ using a Micromeritics ASAP 2460 instrument, all samples were outgassed for $12 \mathrm{~h}$ at $473 \mathrm{~K}$ in a nitrogen flow prior to the physisorption measurements.

Samples for transmission electron microscopy (TEM) inspection were prepared by dispersing the catalyst powder on a porous carbon film supported by a 200 mesh copper TEM grid by ultrasonic dispersion in ethanol. Scanning transmission electron microscopy (STEM) images were obtained with a JEOL JEM-2100F microscope operated at $200 \mathrm{kV}$. For atomic resolution images, AC-HAADF-STEM images were obtained using JEM ARM-200F STEM operating at $200 \mathrm{kV}$.

Infrared spectroscopy using $\mathrm{CO}$ as the probe molecule (CO-IR) was recorded on a BRUKER Equinox 55 spectrometer equipped with an MCT detector, and each spectrum is consist of 32 scans and recorded at a resolution of $4 \mathrm{~cm}^{-1}$. Self-supported catalyst wafers were pressed at $3 \mathrm{kbar}$ pressure for $10 \mathrm{~s}$. The wafer was placed inside a self-designed cell with a $\mathrm{CaF}_{2}$ window. The cell was evacuated and the sample was subsequently reduced at $523 \mathrm{~K}\left(5 \mathrm{~K} \cdot \mathrm{min}^{-1}\right)$ for $1 \mathrm{~h}$ under $10 \mathrm{vol} \% \mathrm{H}_{2} / \mathrm{He}$ flow. The cell was cooled down to $303 \mathrm{~K}$. evacuated again and connected to a gas chamber that permits adjustment of the pressure of $\mathrm{CO}$ injected into the cell. CO adsorption was studied at $303 \mathrm{~K}$ at stepwise increasing exposure time of $\mathrm{CO}$ with the $\mathrm{Rh} @ \mathrm{Al}_{2} \mathrm{O}_{3}$, derived from burning off the carbon species of the $\mathrm{Rh} @ \mathrm{Al}_{2} \mathrm{O}_{3} @ \mathrm{C}$ in the air at $873 \mathrm{~K}$ for $5 \mathrm{~h}$.

${ }^{27} \mathrm{Al}$ MAS NMR measurements were performed on a Bruker Advance III 400WB spectrometer using a $4 \mathrm{~mm}$ probe head. The probe was tuned to $104.3 \mathrm{MHz}$ for ${ }^{27} \mathrm{Al}$. Magic angle spinning at $10 \mathrm{kHz}$ was employed. A single-pulse spectrum was obtained at $9.4 \mathrm{~T}$ with a radio frequency of $62.5 \mathrm{kHz}$. The corresponding relaxation delay and pulse length were $0.1 \mathrm{~s}$ and 1 $\mu \mathrm{s}$, respectively.

X-ray photoelectron spectroscopy (XPS) characterization was performed on a Thermo fisher ESCALAB 250Xi equipped with an $\mathrm{Al} K_{\alpha}$ anode ( $h v=1486.6 \mathrm{eV}$ ). The energy shift due to electrostatic charging was subtracted using the graphitic carbon $\mathrm{C} 1 \mathrm{~s}$ band at $284.6 \mathrm{eV}$.

Temperature-programmed desorption of $\mathrm{NH}_{3}\left(\mathrm{NH}_{3}\right.$-TPD) was carried out on a Micromeritics AutoChem 2920 II instrument. Before measurement, $50 \mathrm{mg}$ of sample loaded in a U-shaped quartz reactor was treated at $473 \mathrm{~K}$ under He gas flow for $2 \mathrm{~h}$ to remove adsorbed species. After cooling down to $300 \mathrm{~K}$, the flowing gas was switched to a $10 \mathrm{vol} \% \mathrm{NH}_{3} / \mathrm{He}$ flow and kept at $493 \mathrm{~K}$ for $1 \mathrm{~h}$ for adsorption. The extra $\mathrm{NH}_{3}$ in gas phase was removed by purge with $\mathrm{He}$ and then $\mathrm{NH}_{3}$-TPD was performed in a He flow by heating the sample up to $973 \mathrm{~K}$ at a rate of $10 \mathrm{~K} \cdot \mathrm{min}^{-1}$.

All Spin-polarized periodic density functional theory (DFT) calculations were performed using the Vienna ab initio simulation package (VASP 5.4.4) with a generalized gradient-approximated (GGA) with the Perdew-Burke-Ernzerhof (PBE) functional $[28,29]$. The electron-ion interactions were described with the projected augmented waves (PAW) method and the energy cutoff was set to $400 \mathrm{eV}$ [30]. For structural optimizations, calculations were finished until the total energy was converged to $10^{-5} \mathrm{eV}$ and the convergence criterion of force was less than $0.05 \mathrm{eV} / \AA ̊$. The van der Waals (vdW) interactions were included by using Grimme's DFT-D3 (BJ) method [31]. The transition states were searched using the climbing-image nudged elastic band (CI-NEB) method [32], four to eight NEB images generated by the image-dependent pair potentials (IDPP) method [33], and each transition state was reconfirmed with only one imaginary frequency. In all calculations, two layers in the bottom of models were fixed and the rest atoms were allowed to fully relax, and a $15 \AA$ vacuum layer was used along the $c$ direction to avoid periodic interactions. A $2 \times 2 \times 1$ Monkhorst-Pack $k$-points were used to sample the Brillouin zone. The adsorption energies of $\mathrm{Rh}_{n}(n=1-4)$ clusters on the $\gamma-\mathrm{Al}_{2} \mathrm{O}_{3}(100)$ were calculated according to the equation $E_{\text {ads }}$ $=E_{\text {(surface }+ \text { adsorbate) }}-E_{\text {(surface) }}-E_{\text {(adsorbate), where }} E_{\text {(surface }+ \text { adsorbate) }}$ represents the total energy of the $\gamma-\mathrm{Al}_{2} \mathrm{O}_{3}(100)$ surface slab and the adsorbed $\mathrm{Rh}_{\mathrm{n}}$ cluster, $E_{\text {(surface) }}$ is the energy of the pure $\gamma-\mathrm{Al}_{2} \mathrm{O}_{3}(100)$ surface, and $E_{\text {(adsorbate) }}$ is the energy of the optimized $\mathrm{Rh}_{\mathrm{n}}$ cluster in the gas phase.

\subsection{Catalytic tests and product analysis}

The selective hydrogenation of $m$-chloronitrobenzene ( $m$-CNB) was carried out in a $10 \mathrm{~mL}$ Teflon-lined autoclave reactor. For a typical reaction, $m$-CNB $(78.8 \mathrm{mg}, 0.5 \mathrm{mmol})$, toluene $(2 \mathrm{~mL})$, different catalyst samples $(30 \mathrm{mg}$ ) was mixed in the autoclave reactor. Tetradecane (Aladdin, 99.5\%) was also added as an internal standard. The reactor was then sealed, purged three times with $\mathrm{N}_{2}$ and charged with 20 bar of $\mathrm{H}_{2}$. Then the reactor was heated to $313 \mathrm{~K}$ in a water bath and kept at this temperature for $0.5-12 \mathrm{~h}$ under vigorous stirring. After reaction, the autoclave was cooled to room temperature, $\mathrm{H}_{2}$ was released. The catalyst was collected by filtration, washed with toluene and dried overnight at $333 \mathrm{~K}$. For the recycling experiment, the dried catalyst was transferred back to 


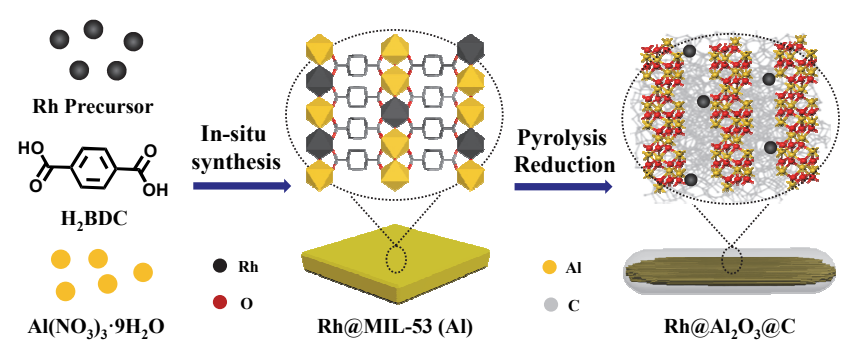

Scheme 1. Schematic illustration for the synthesis of the $\mathrm{Rh} @ \mathrm{Al}_{2} \mathrm{O}_{3} @ \mathrm{C}$.

the reactor and a new batch of substrate was added under standard reaction conditions for a new catalytic run. The reaction products were analyzed using an Agilent GC (7890B) gas chromatograph and identified with an Agilent GC-MS (7890B-5977A MSD), both equipped with an Agilent HP-5 (30 $\mathrm{m} \times 0.32 \mathrm{~mm} \times 0.25 \mu \mathrm{m})$ column and a flame ionization detector (FID).

\section{Results and discussion}

\subsection{Synthesis and characterizations of catalysts}

The $\mathrm{Rh} @ \mathrm{Al}_{2} \mathrm{O}_{3} @ \mathrm{C}$ is fabricated via a two-step process utilizing MIL-53 (Al) as a scaffold, as illustrated in Scheme 1. First, a solution of $\mathrm{RhCl}_{3}$ is introduced during the assembly process of MIL-53 (Al), to graft Rh atoms into MIL-53 (Al) and form Rh@MIL-53 (Al). Atomic distribution of Rh species is thus achieved by dispersing mononuclear Rh precursors into the MIL-53 (Al). The obtained Rh@MIL-53 (Al) is followed by pyrolysis at $873 \mathrm{~K}$ under Ar atmosphere and subsequently reduced in diluted $\mathrm{H}_{2}$, to form the $\mathrm{Rh}_{0} @ \mathrm{Al}_{2} \mathrm{O}_{3} @ \mathrm{C}$. Compared to the MOF-based materials, the obtained material after pyrolysis shows an improved stability under hydrothermal conditions, thus more suitable as catalyst.

The XRD patterns of the MIL-53 (Al), Rh@MIL-53 (Al), $\mathrm{Al}_{2} \mathrm{O}_{3} @ \mathrm{C}$ and $\mathrm{Rh} @ \mathrm{Al}_{2} \mathrm{O}_{3} @ \mathrm{C}$ materials are shown in Fig. 1. The XRD pattern of Rh@MIL-53 (Al) shows similar diffraction reflection positions as that of MIL-53 (Al) [34], indicating that the addition of $\mathrm{RhCl}_{3}$ has limited impact on the assembly of MIL-53 (Al) framework. After the thermal pyrolysis process, the $\mathrm{Rh} @ \mathrm{Al}_{2} \mathrm{O}_{3} @ \mathrm{C}$ shows new diffraction peaks at $2 \theta=37.6^{\circ}, 45.8^{\circ}$,

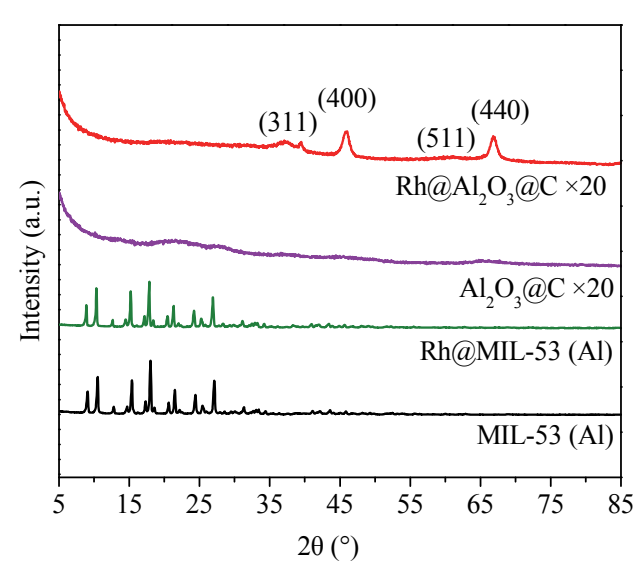

Fig. 1. XRD patterns of the MIL-53 (Al), the Rh@MIL-53 (Al), the $\mathrm{Al}_{2} \mathrm{O}_{3} @ \mathrm{C}$ and the $\mathrm{Rh} @ \mathrm{Al}_{2} \mathrm{O}_{3} @ \mathrm{C}$.

$60.9^{\circ}$ and $67.0^{\circ}$, corresponding to the (311), (400), (511) and (440) lattice planes of $\gamma-\mathrm{Al}_{2} \mathrm{O}_{3}$ (JCPDS Card 10-425). Meanwhile, the $\mathrm{Al}_{2} \mathrm{O}_{3} @ \mathrm{C}$ obtained after pyrolysis of MIL-53 (Al) shows no crystallized phase in the XRD patterns, pointing to the amorphous phase of $\mathrm{Al}_{2} \mathrm{O}_{3}$ and carbon. Compared to the $\mathrm{Al}_{2} \mathrm{O}_{3} @ \mathrm{C}$, the $\mathrm{Rh} @ \mathrm{Al}_{2} \mathrm{O}_{3} @ \mathrm{C}$ shows a crystallized phase of $\gamma-\mathrm{Al}_{2} \mathrm{O}_{3}$, indicating that the addition of Rh possibly benefits the crystallization of $\mathrm{Al}_{2} \mathrm{O}_{3}$. Additionally, no apparent Rh-phase reflections are observed for the $\mathrm{Rh} / \gamma-\mathrm{Al}_{2} \mathrm{O}_{3}, \mathrm{Rh} / \mathrm{C}$ and $\mathrm{Rh} @ \mathrm{Al}_{2} \mathrm{O}_{3} @ \mathrm{C}$ at this low metal loading of 0.1 wt $\%$ in the XRD patterns (Fig. 1 and Fig. S2), indicating a good dispersion of Rh on the support.

Surface areas and pore size distributions for different materials were determined by $\mathrm{N}_{2}$ physisorption (Fig. 2 and Table 1). Prior to testing, the MIL-53 (Al) and Rh@MIL-53 (Al) samples were pretreated at $573 \mathrm{~K}$ for $72 \mathrm{~h}$ to remove terephthalic acid remaining in the pores. Both of them show typical type-I isotherms with microporous structure (Fig. 2(a)). Compared to MIL-53 (Al) material, the Rh@MIL-53 (Al) shows a slight decrease in the BET surface area from 1451 to $1109 \mathrm{~m}^{2} \cdot \mathrm{g}^{-1}$ (Table 1). Besides, the diameter of pore size also decreased from 0.72 to $0.62 \mathrm{~nm}$ (Fig. 2(b)), referring to the successful encapsulation of Rh species into the micropores of MIL-53 (Al). After thermal pyrolysis, the obtained $\mathrm{Rh} @ \mathrm{Al}_{2} \mathrm{O}_{3} @ \mathrm{C}$ shows a significant drop

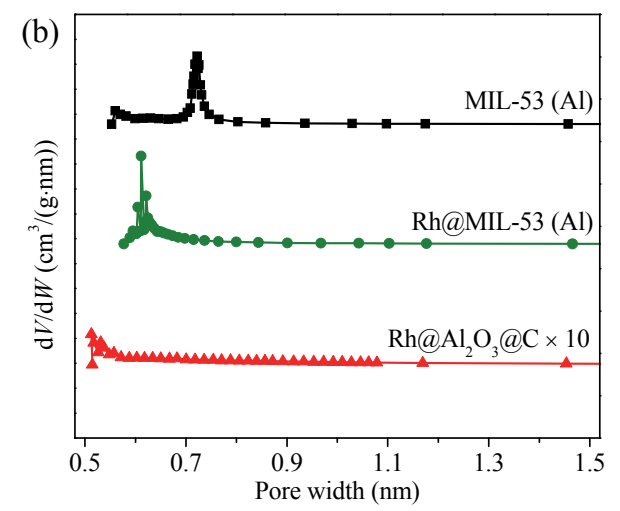

Fig. 2. $\mathrm{N}_{2}$ adsorption-desorption isotherms (a) and pore size distributions (b) of the MIL-53 (Al), the Rh@MIL-53 (Al) and the Rh@Al $\mathrm{O}_{3} @ \mathrm{C}$. 
Table 1

Physicochemical properties of different samples under study.

\begin{tabular}{|c|c|c|c|c|c|}
\hline Catalysts & $\begin{array}{c}\text { BET } \\
\text { surface } \\
\text { area } \\
\left(\mathrm{m}^{2} \cdot \mathrm{g}^{-1}\right)\end{array}$ & $\begin{array}{c}\text { Micropore } \\
\text { surface } \\
\text { area }^{\text {a }} \\
\left(\mathrm{m}^{2} \cdot \mathrm{g}^{-1}\right)\end{array}$ & $\begin{array}{c}\text { External } \\
\text { surface } \\
\text { area }^{\mathrm{a}} \\
\left(\mathrm{m}^{2} \cdot \mathrm{g}^{-1}\right)\end{array}$ & $\begin{array}{c}\text { Micropore } \\
\text { volume } \\
\left(\mathrm{cm}^{3} \cdot \mathrm{g}^{-1}\right)\end{array}$ & $\begin{array}{c}\mathrm{Rh} \\
\text { loading } \\
(\mathrm{wt} \% \text { ) }\end{array}$ \\
\hline MIL-53 (Al) & 1451 & 1001 & 450 & 0.498 & - \\
\hline Rh@MIL-53 (Al) & 1109 & 770 & 338 & 0.402 & - \\
\hline $\mathrm{Rh} @ \mathrm{Al}_{2} \mathrm{O}_{3} @ \mathrm{C}$ & 219 & 78 & 141 & 0.040 & $0.1^{\mathrm{d}}$ \\
\hline $\begin{array}{l}\mathrm{Rh} @ \mathrm{Al}_{2} \mathrm{O}_{3} @ \mathrm{C} \\
\text { (spent) } \mathrm{b}\end{array}$ & 180 & 58 & 122 & 0.031 & $0.1^{\mathrm{d}}$ \\
\hline $\mathrm{Rh} / \gamma-\mathrm{Al}_{2} \mathrm{O}_{3}$ & 174 & $-{ }^{c}$ & 178 & $-^{\mathrm{c}}$ & $0.1^{d}$ \\
\hline $\mathrm{Rh} / \mathrm{C}$ & 1472 & 598 & 875 & 0.309 & $0.1^{\mathrm{d}}$ \\
\hline
\end{tabular}

a Obtained by the t-plot method.

b After one catalytic run.

c Below the detection limit of $\mathrm{N}_{2}$ physisorption isotherms.

d Determined by ICP-OES analysis.

in porosity (BET surface area from 1109 to $219 \mathrm{~m}^{2} \cdot \mathrm{g}^{-1}$, Table 1), pointing to the decomposition of the linkers of MIL-53 (Al). Meanwhile, The BET surface area of the benchmark catalysts is $174 \mathrm{~m}^{2} \cdot \mathrm{g}^{-1}$ for $\mathrm{Rh} / \gamma-\mathrm{Al}_{2} \mathrm{O}_{3}$, and $1472 \mathrm{~m}^{2} \cdot \mathrm{g}^{-1}$ for $\mathrm{Rh} / \mathrm{C}$ respectively (Table 1).

The STEM images of the Rh@MIL-53 (Al) and the $\mathrm{Rh} @ \mathrm{Al}_{2} \mathrm{O}_{3} @ \mathrm{C}$ are shown in Fig. 3. Clearly, the Rh@MIL-53 (Al) presents smooth-surfaced diamond-shaped particles with a diameter of about $1 \mu \mathrm{m}$ (Fig. 3(a) and 3(b)), in line with the reported structure of the MIL-53 (Al) [34]. After pyrolysis, the obtained $\mathrm{Rh} @ \mathrm{Al}_{2} \mathrm{O}_{3} @ \mathrm{C}$ transfers to a spindle-shaped morphology with a rough surface (Fig. 3(c) and 3(d)), owing to the de-

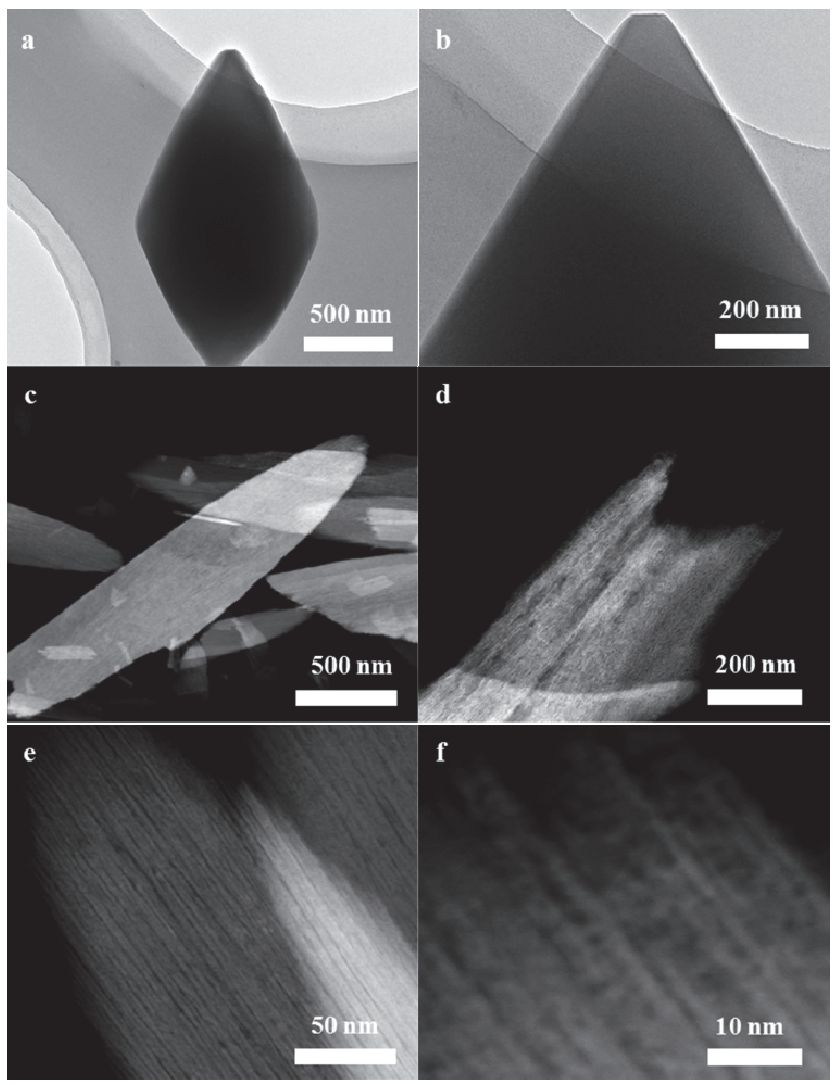

Fig. 3. STEM images of the Rh@MIL-53 (Al) (a,b) and the Rh@ $\mathrm{Al}_{2} \mathrm{O}_{3} @ \mathrm{C}$ (c-f). construction of MIL-53 (Al) structure during pyrolysis, consistent with previous reports [35,36]. Notably, at the higher magnification, an aligned fibrous structure is visualized for the $\mathrm{Rh} @ \mathrm{Al}_{2} \mathrm{O}_{3} @ \mathrm{C}$ (Fig. 3(e) and 3(f)). No appreciable Rh nanoparticles were detected for the $\mathrm{Rh} @ \mathrm{Al}_{2} \mathrm{O}_{3} @ \mathrm{C}$ in STEM, indicating a

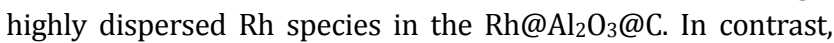
the average $\mathrm{Rh}$ particle size is visualized to be $\sim 1.0 \mathrm{~nm}$ for the $\mathrm{Rh} / \gamma-\mathrm{Al}_{2} \mathrm{O}_{3}$ and $\sim 2.1 \mathrm{~nm}$ for the $\mathrm{Rh} / \mathrm{C}$ respectively (Fig. S3).

To obtain insights into the structural information of the Rh species in the $\mathrm{Rh} @ \mathrm{Al}_{2} \mathrm{O}_{3} @ \mathrm{C}, \mathrm{AC}-\mathrm{STEM}$ was conducted in the HAADF. Clearly, well-dispersed isolated Rh atoms as bright dots (circled by white rounds) are readily visualized in different regions of the $\mathrm{Rh} @ \mathrm{Al}_{2} \mathrm{O}_{3} @ \mathrm{C}$ (Fig. 4). Combining with no detected $\mathrm{Rh}$ clusters or nanoparticles in STEM, the domain presence of single-atom Rh sites in the $\mathrm{Rh} @ \mathrm{Al}_{2} \mathrm{O}_{3} @ \mathrm{C}$ is thus confirmed. In addition, an interplanar spacing of $0.2 \mathrm{~nm}$ is also observed from AC-HAADF-STEM images, associated with the (400) lattice plane of $\gamma-\mathrm{Al}_{2} \mathrm{O}_{3}$ [37]. To confirm the validity of the single-atom feature of Rh sites, FT-IR spectra of $\mathrm{CO}$ adsorption were measured for the $\mathrm{Rh} @ \mathrm{Al}_{2} \mathrm{O}_{3}$ (Fig. 5(a)), obtained by removing the amorphous carbon species of the $\mathrm{Rh} @ \mathrm{Al}_{2} \mathrm{O}_{3} @ \mathrm{C}$ by thermal pyrolysis at $873 \mathrm{~K}$ for $5 \mathrm{~h}$ in the air flow. Spectra with good quality are thus obtained without the interference of carbon materials at a temperature of $303 \mathrm{~K}$. The spectra show no development of features of bridged-CO species on Rh (around $1860 \mathrm{~cm}^{-1}$ ) over time, indicating the absence of Rh clusters or particles [38], in line with AC-HAADF-STEM results that Rh species are present as isolated sites on the $\mathrm{Rh} @ \mathrm{Al}_{2} \mathrm{O}_{3} @ \mathrm{C}$. Two primary features at 2016 and $2087 \mathrm{~cm}^{-1}$ appear with the increase of CO exposing time, corresponding to the symmetric and asymmetric stretching of gem-dicarbonyl species on positively charged Rh atoms respectively $[39,40]$. Notably, the location of features remains unchanged as the increase of $\mathrm{CO}$ exposing time, again pointing to the single-atom feature of $\mathrm{Rh}$ species [41]. A feature at $2060 \mathrm{~cm}^{-1}$ develops after a CO exposing time of $2 \mathrm{~min}$, associated with the linear-CO species on $\mathrm{Rh}^{\delta+}$ sites [42,43]. The two broad features at around 2120 and 2170 $\mathrm{cm}^{-1}$ are assigned to the gaseous CO [44]. The CO-IR data reveals the atomic dispersion of $\mathrm{Rh}^{\delta+}$ on the $\mathrm{Al}_{2} \mathrm{O}_{3}$ even after burning-off the carbon species, indicating a strong interaction between $\mathrm{Rh}^{\delta+}$ and $\mathrm{Al}_{2} \mathrm{O}_{3}$.

It has been reported that the unsaturated five-coordinated aluminum species $\left(\mathrm{Al}^{\mathrm{V}}\right)$, providing anchor sites for metal atoms, plays a pivotal role in the formation of single-atom metal sites on alumina supports $[45,46]$. Solid-state ${ }^{27} \mathrm{Al}$ MAS NMR measurements were therefore performed for inspecting the presence of such species in the $\mathrm{Rh} @ \mathrm{Al}_{2} \mathrm{O}_{3} @ \mathrm{C}$ SAC. The Rh/ $\gamma-\mathrm{Al}_{2} \mathrm{O}_{3}$

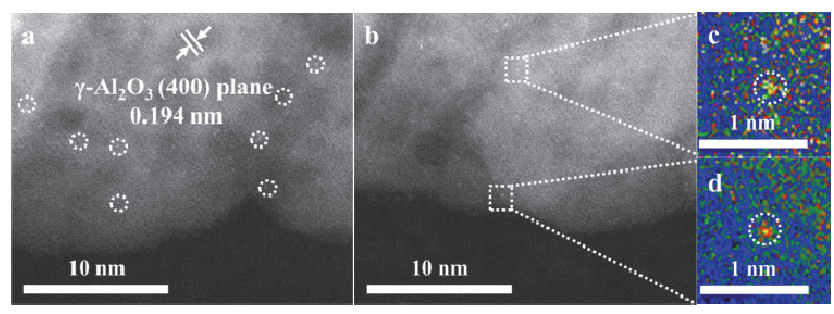

Fig. 4. AC-HAADF-STEM images of the $\mathrm{Rh} @ \mathrm{Al}_{2} \mathrm{O}_{3} @ \mathrm{C}$ in grey $(\mathrm{a}, \mathrm{b})$ and in color $(\mathrm{c}, \mathrm{d})$. 

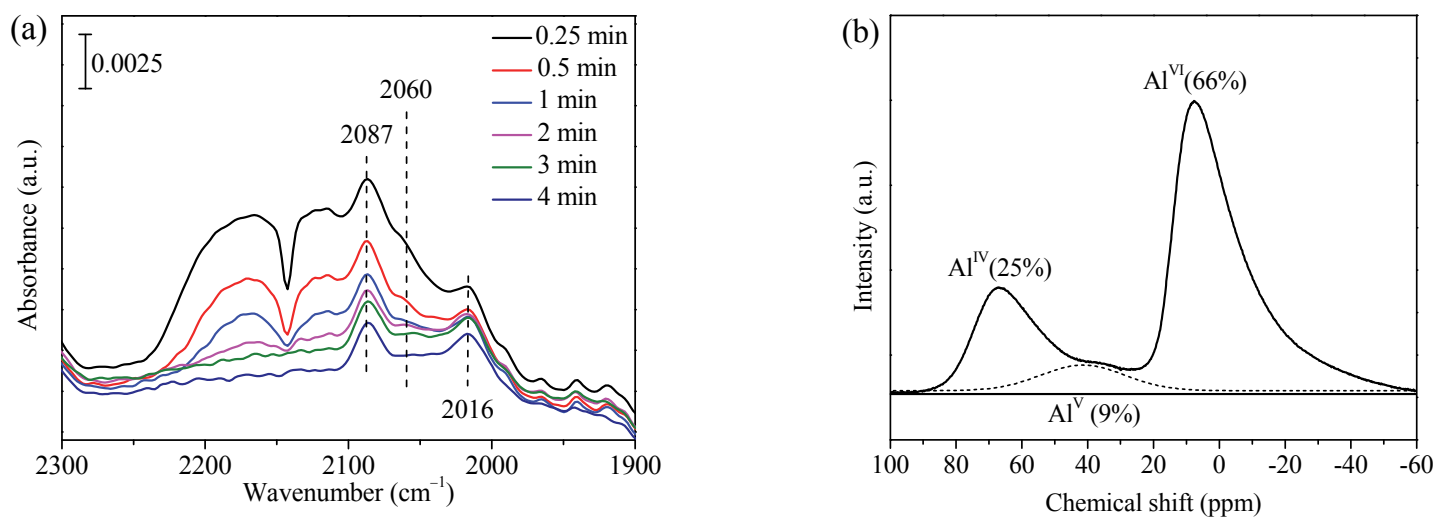

Fig. 5. (a) FT-IR spectra of CO adsorption over the $\mathrm{Rh} @ \mathrm{Al}_{2} \mathrm{O}_{3}$; (b) ${ }^{27} \mathrm{Al} M A S$ NMR spectra of the $\mathrm{Rh} @ \mathrm{Al}_{2} \mathrm{O}_{3} @ \mathrm{C}$.

nanocatalyst and $\mathrm{Al}_{2} \mathrm{O}_{3} @ \mathrm{C}$ support, prepared by pyrolysis of MIL-53 (Al) under the same condition of $\mathrm{Rh} @ \mathrm{Al}_{2} \mathrm{O}_{3} @ \mathrm{C}$ were also employed as contrast catalysts. As shown in Fig. 5(b) and Fig. S4, three resonances, with an isotropic shift of around 5, 35, and 67 ppm, are visualized for both of the $\mathrm{Rh} @ \mathrm{Al}_{2} \mathrm{O}_{3} @ \mathrm{C}$ and the $\mathrm{Al}_{2} \mathrm{O}_{3} @ \mathrm{C}$, representing four-coordinated ( $\mathrm{Al}^{\mathrm{IV}}$ ), five-coordinated (AlV) and six-coordinated (AlvI) aluminum species respectively [45]. The $\mathrm{Al}^{\mathrm{V}}$ sites are probably derived from thermal pyrolysis of MIL-53 (Al) at elevated temperatures, serving as the anchoring sites for isolated $\mathrm{Rh}$ atoms via a strong interaction. Notably, a significant amount of $\mathrm{Al}^{\mathrm{V}}(23 \%)$ is indeed present in the $\mathrm{Al}_{2} \mathrm{O}_{3} @ \mathrm{C}$, which is much higher than that in the $\mathrm{Rh} @ \mathrm{Al}_{2} \mathrm{O}_{3} @ \mathrm{C}(9 \%)$. This is also in line with the XRD results of the lower crystallinity of $\mathrm{Al}_{2} \mathrm{O}_{3} @ \mathrm{C}$ compared to $\mathrm{Rh} @ \mathrm{Al}_{2} \mathrm{O}_{3} @ \mathrm{C}$ (Fig. 1). Instead, no Alv species is observed for the $\mathrm{Rh} / \gamma-\mathrm{Al}_{2} \mathrm{O}_{3}$ (Fig. S5). Combining with the observed Rh nanoparticles of about $1.0 \mathrm{~nm}$ in the $\mathrm{Rh} / \gamma-\mathrm{Al}_{2} \mathrm{O}_{3}$ by STEM and previous reports of the significant contribution of $\mathrm{Al}^{\mathrm{V}}$ species for the preparation of single-atom catalysts (SAC) [47], it is highly rational to ascribe the successful preparation of SAC to the presence of the $\mathrm{Al}^{\mathrm{V}}$ species in the $\mathrm{Rh} @ \mathrm{Al}_{2} \mathrm{O}_{3} @ \mathrm{C}$, providing unsaturated anchoring sites for metal atoms.

DFT calculations were conducted to further validate the critical role of the $\mathrm{Al}^{\mathrm{V}}$ species for anchoring $\mathrm{Rh}$ single atoms. The employed surface model of $\gamma-\mathrm{Al}_{2} \mathrm{O}_{3}(100)$, which is the only

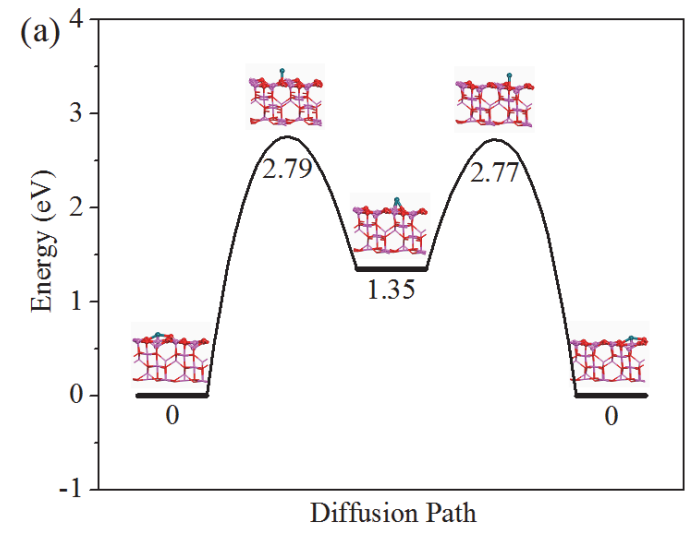

facet exposing $\mathrm{Al}^{\mathrm{V}}$ species, was based on previously established models [48,49] (Fig. S6). The stability of Rh atoms is mainly related to the structural evolution including adsorption, migration, and aggregation of $\mathrm{Rh}_{\mathrm{n}}$ clusters on the support. As shown in Table S1 and Fig. S7, the Rh single atoms and clusters adsorb strongly on the $\gamma-\mathrm{Al}_{2} \mathrm{O}_{3}$ surface with adsorption energies in the range from -3.86 to $-2.79 \mathrm{eV}$, indicating the strong bond in Rh-AlV pairs [50]. High migration energy barriers (Fig. 6(a)) indicate that it is very thermodynamically and kinetically unfavorable for the migration of isolated $\mathrm{Rh}$ atoms from the most stable adsorption sites. Furthermore, the first step of the nucleation from single $\mathrm{Rh}$ atoms needs the formation of $\mathrm{Rh}$ dimers (Fig. 6(b)) [51], which is endothermic by $0.35 \mathrm{eV}$, indicating the unfavorableness of the nucleation of the isolated $\mathrm{Rh}$ atoms on the $\mathrm{Alv}^{\mathrm{V}}$ sites. Indeed, DFT calculations confirm a stable and strong interaction between $\mathrm{Rh}$ single atoms and $\mathrm{Al}^{\mathrm{V}}$ sites, which is unfavorable for structural migration and aggregation on the $\gamma-\mathrm{Al}_{2} \mathrm{O}_{3}$ support.

\subsection{Selective hydrogenation of m-chloronitrobenzene into m-chloroaniline}

The catalytic performance of the $\mathrm{Rh} @ \mathrm{Al}_{2} \mathrm{O}_{3} @ \mathrm{C}$ SAC was evaluated in selective hydrogenation of $m$-chloronitrobenzene ( $m$-CNB) into $m$-chloroaniline $(m$-CAN) under batch conditions

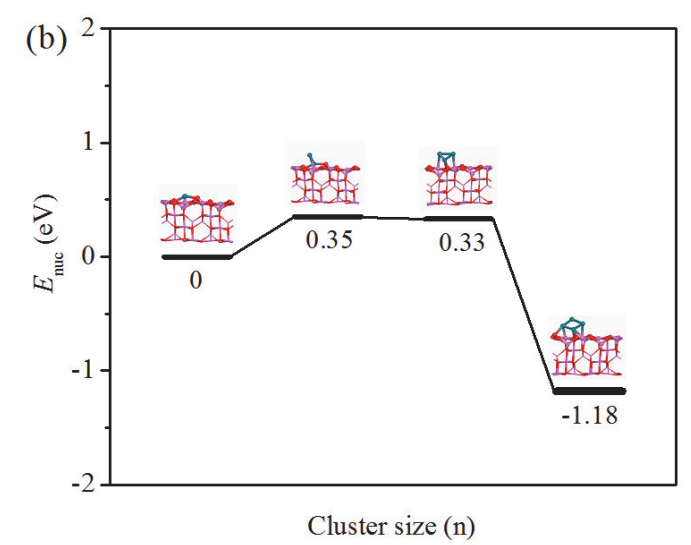

Fig. 6. (a) The migration energetic diagram of single $\mathrm{Rh}$ atoms on the $\gamma$ - $\mathrm{Al}_{2} \mathrm{O}_{3}(100)$ surface; (b) nucleation energies $E_{\text {nuc }}$ of the aggregation from $\mathrm{Rh}$ to $\mathrm{Rh}_{4}$ on the $\gamma-\mathrm{Al}_{2} \mathrm{O}_{3}(100)$ surface. Red, pink and dark cyan balls represent $\mathrm{O}, \mathrm{Al}$, and $\mathrm{Rh}$ atoms, respectively. 
at $313 \mathrm{~K}$ and 20 bar $\mathrm{P}_{\mathrm{H} 2}$. The contrast experiments were also performed with the $\mathrm{Rh} / \gamma-\mathrm{Al}_{2} \mathrm{O}_{3}$ and $\mathrm{Rh} / \mathrm{C}$ nanocatalysts as benchmark catalysts. The time-on-line concentration profiles of substrates and products under different catalysts and reaction scheme are depicted in Fig. 7. The $\mathrm{Rh}_{0} \mathrm{Al}_{2} \mathrm{O}_{3} @ \mathrm{C}$ SAC achieved a quantitative conversion of $m$-CNB and a $m$-CAN yield of $99 \%$ within $2.5 \mathrm{~h}$, indicating an excellent performance in both activity and selectivity (Fig. 7(a)). Furthermore, the yield of $m$-CAN could retain at $99 \%$ even with an extended reaction time of 12 h. Additionally, this SAC can afford a significant $m$-CNB turnover frequency (TOF) of $2317 \mathrm{~mol}_{m-\mathrm{CNB}} \cdot \mathrm{mol}_{\mathrm{Rh}^{-1}} \cdot \mathrm{h}^{-1}$, which is the highest value to date, in heterogeneous catalyst systems at such a mild temperature of $313 \mathrm{~K}[22,24,52-60]$. At the early stage of $m$-CNB (1) hydrogenation, $m$-chlorophenylhydroxylamine (3) and 3, 3'-dichloroazoxybenzene (4), formed by coupling of $m$-nitrosochlorobenzene (2) and (3), were observed as the primary intermediates for the $\mathrm{Rh}_{\mathrm{A}} \mathrm{Al}_{2} \mathrm{O}_{3} @ \mathrm{C}$ (Fig. 7(d)). For the $\mathrm{Rh} / \gamma-\mathrm{Al}_{2} \mathrm{O}_{3}$ nanocatalyst, an inferior activity is observed with a TOF of $661 \mathrm{~mol}_{m-\mathrm{CNB}} \cdot \mathrm{mol}_{\mathrm{Rh}^{-1}} \cdot \mathrm{h}^{-1}$, with a $m$-CNB conversion of $99 \%$ and a $m$-CAN yield of $91 \%$ at a reaction time of $4 \mathrm{~h}$ (Fig. 7(b)). A significant amount of cyclohexylamine (7) (30\%) via an intermediate of aniline (6) was formed as a by-product, at the expense of $m$-CAN (5), by consecutive hydrogenation reactions (Fig. 7(d)). Similar observation of over-hydrogenation has also been demonstrated with other nanocatalysts for the selective hydrogenation of $m$-CNB to $m$-CAN $[25,53]$. Comparatively, the $\mathrm{Rh} / \mathrm{C}$ nanocatalyst shows a low activity, with an $m$-CNB conversion of $61 \%$ and an $m$-CAN yield of $59 \%$ in $12 \mathrm{~h}$ (Fig. 7 (c)). This corresponds to a TOF of $122 \mathrm{~mol}_{m-\mathrm{CNB}} \cdot \mathrm{mol}_{\mathrm{Rh}}{ }^{-1} \cdot \mathrm{h}^{-1}$, comparable with the values of reported $\mathrm{Pd} / \mathrm{C}$ and $\mathrm{Pt} / \mathrm{C}$ nano- catalysts $[61,62]$.

As shown in Fig. 7(d), two different routes from $m$-CNB to $m$-CAN are depicted, involving sequential hydrogenation, hydrogenolysis, dehydration and dechlorination reactions, which require a good combination of different function sites (metal and acid sites). Therefore, the chemical state of metal and the acid amount of the catalyst materials are essential for the catalytic performance. To explore insight into the enhanced performance of the $\mathrm{Rh} @ \mathrm{Al}_{2} \mathrm{O}_{3} @ \mathrm{C}, \mathrm{XPS}$ (Fig. 8) and $\mathrm{NH}_{3}$-TPD (Fig. S8) measurements were performed for the $\mathrm{Rh}_{\mathrm{A}} \mathrm{Al}_{2} \mathrm{O}_{3} @ \mathrm{C} \mathrm{SAC}$ and two contrast nanocatalysts $\left(\mathrm{Rh} / \gamma-\mathrm{Al}_{2} \mathrm{O}_{3}\right.$ and $\left.\mathrm{Rh} / \mathrm{C}\right)$. In the $\mathrm{Rh} 3 d$ signal, a feature at a binding energy of $308.5 \mathrm{eV}$, assigned to the positively charged $\mathrm{Rh}^{\delta+}$ species, is mainly present in the

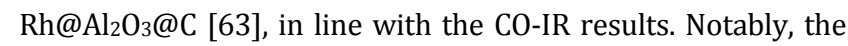
$\mathrm{NH}_{3}$-TPD results show a largest amount of total acidity for the $\mathrm{Rh} @ \mathrm{Al}_{2} \mathrm{O}_{3} @ \mathrm{C}\left(0.054 \mathrm{mmol} \cdot \mathrm{g}^{-1}\right)$ among the three catalysts. Compared to the $\mathrm{Rh} / \gamma-\mathrm{Al}_{2} \mathrm{O}_{3}$, the increased acid amount of the $\mathrm{Rh} @ \mathrm{Al}_{2} \mathrm{O}_{3} @ \mathrm{C}$, is associated with the aligned fibrous shape of $\gamma-\mathrm{Al}_{2} \mathrm{O}_{3}$ in the well-defined structure, which can significantly enhance the acid accessibility of the material. Based on the time-on-line profiles and reaction mechanism (Fig. 7(a) and $7(d)$ ), the excellent activity and selectivity of the $\mathrm{Rh}_{0} \mathrm{Al}_{2} \mathrm{O}_{3} @ \mathrm{C}$ originate from the combination of modulated hydrogenation sites $\left(\mathrm{Rh}^{\delta+}\right)$ and the good accessibility of the acid sites. The single-atom sites are normally with positively charged chemical state, showing weakened hydrogenation ability compared to their nanoscale counterparts. Such modulation of hydrogenation ability has shown to be an advantage in efficiently avoiding over-hydrogenation [20,21]. Additionally, the reaction intermediates of $m$-chlorophenylhydroxylamine (3) and 3 ,
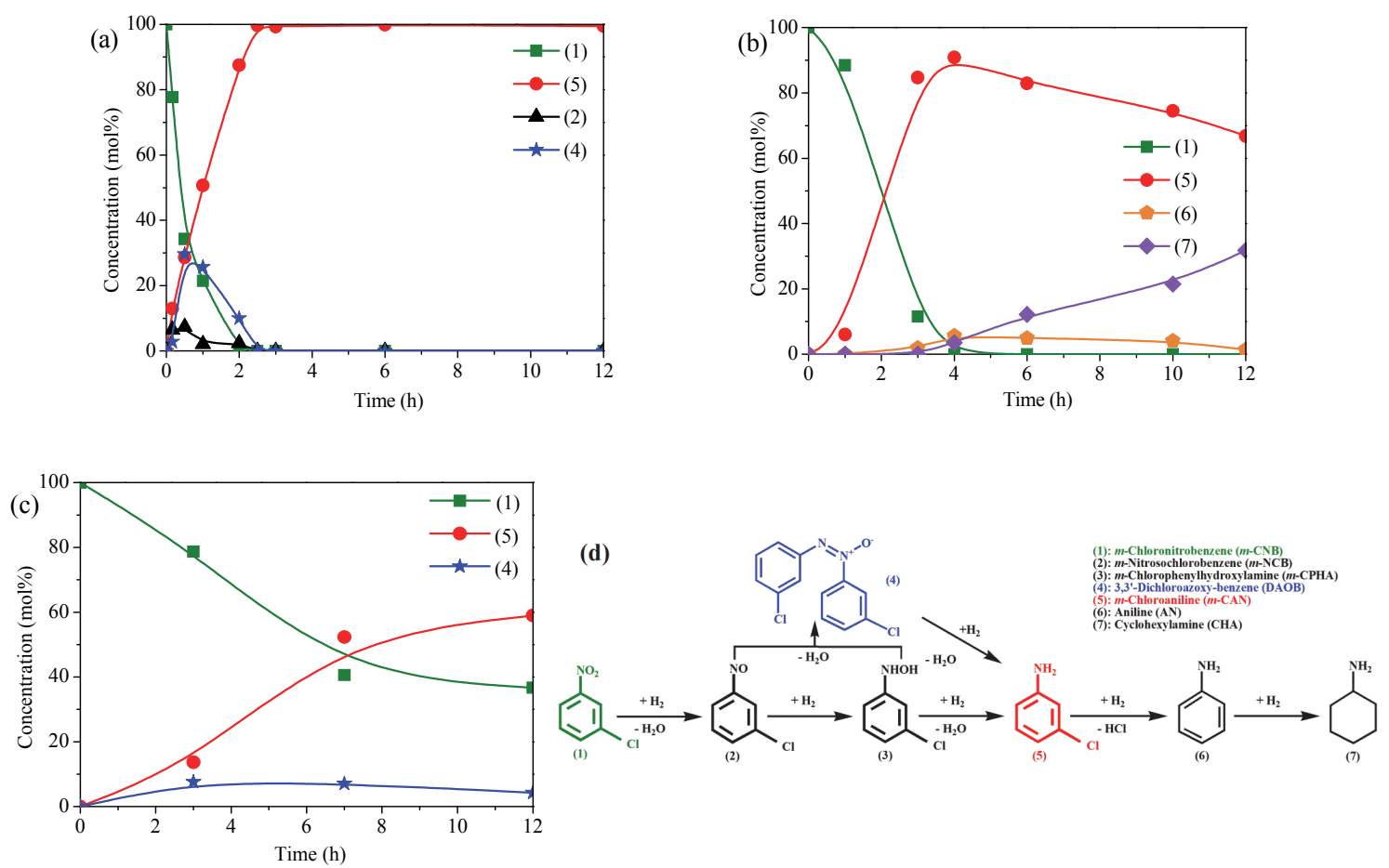

Fig. 7. Time profiles of selective hydrogenation of $m$-chloronitrobenzene using the $\mathrm{Rh} @ \mathrm{Al}_{2} \mathrm{O}_{3} @ \mathrm{C}(\mathrm{a})$, the $\mathrm{Rh} / \gamma$ - $\mathrm{Al}_{2} \mathrm{O}_{3}(\mathrm{~b})$ and the $\mathrm{Rh} / \mathrm{C}(\mathrm{c})$ as the catalysts; (d) catalytic routes of selective hydrogenation of $m$-chloronitrobenzene to $m$-chloroaniline. Reaction conditions: $T=313 \mathrm{~K}, P_{\mathrm{H} 2}=20 \mathrm{bar}, 30 \mathrm{mg}$ catalyst, $0.5 \mathrm{mmol} m$-chloronitrobenzene, $2 \mathrm{~mL}$ toluene. 


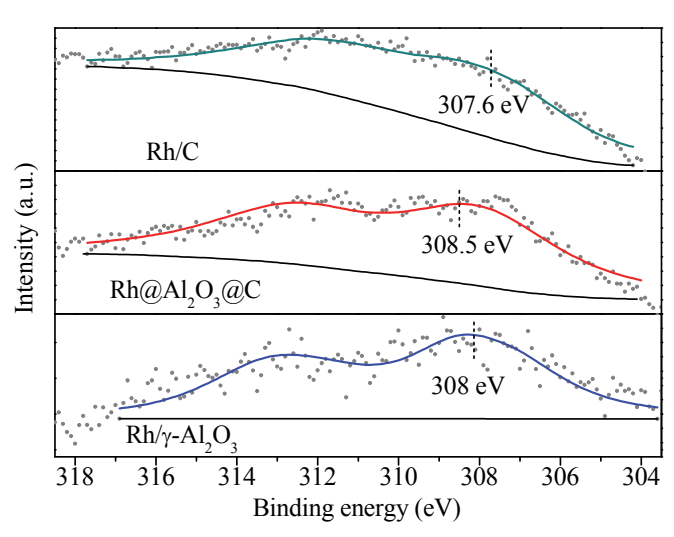

Fig. 8. $\mathrm{Rh} 3 d$ XPS spectra of the $\mathrm{Rh} / \mathrm{C}$, the $\mathrm{Rh} / \gamma-\mathrm{Al}_{2} \mathrm{O}_{3}$ and the $\mathrm{Rh} @ \mathrm{Al}_{2} \mathrm{O}_{3} @ \mathrm{C}$.

3'-dichloroazoxybenzene (4) are often observed when the metal sites are with decreased hydrogenation ability [64]. The acid sites can facilitate the dehydration reactions involved in the reaction scheme, especially at this relatively low temperature

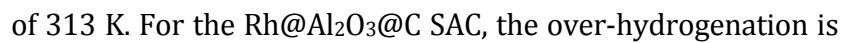
efficiently avoided owing to the proper modulation of hydrogenation metal by forming SAC, and the presence of a significant amount of acid sites enhances the formation of the target $m$-CAN. Instead, the $\mathrm{Rh} / \gamma-\mathrm{Al}_{2} \mathrm{O}_{3}$ shows a combination of active nanoparticles $(\sim 1 \mathrm{~nm})$ and a medium amount of acid sites $\left(0.036 \mathrm{mmol} \cdot \mathrm{g}^{-1}\right)$, and the main issue of this nanocatalyst is the lack of control on consecutive hydrogenation reactions, resulting in a significant decrease in selectivity at the extended reaction time. Comparatively, the formation of a large nanoparticles $(\sim 2.1 \mathrm{~nm})$ is observed for the $\mathrm{Rh} / \mathrm{C}$ at this relatively low $\mathrm{Rh}$ loading of $0.1 \mathrm{wt} \%$, together with a small amount of acid site $\left(0.006 \mathrm{mmol} \cdot \mathrm{g}^{-1}\right)$. Owing to the significant decrease in active sites, the $\mathrm{Rh} / \mathrm{C}$ displays a much lower activity, with reactions staying primarily in the early stage. Therefore, a proper modulation of electronic structure of hydrogenation metal by forming SAC, together with an enhanced accessibility of acid sites, has been achieved for the $\mathrm{Rh} @ \mathrm{Al}_{2} \mathrm{O}_{3} @ \mathrm{C}$ via an in-situ synthesis approach, providing an enhanced chemoselectivity for the selective hydrogenation of $m$-CNB to $m$-CAN.

The stability of the $\mathrm{Rh} @ \mathrm{Al}_{2} \mathrm{O}_{3} @ \mathrm{C}$ SAC was further examined by performing multiple recycling tests under the applied conditions. Catalytic activity and selectivity were compared at different $m$-CNB conversion levels. As shown in Fig. S9, the activity and $m$-CAN selectivity are sustained over this SAC at a $m$-CNB conversion of $65 \%$ upon three multiple reuse. Additionally, even at a prolonged reaction time of $12 \mathrm{~h}$, this SAC could be reused for at least five consecutive runs without an apparent drop in activity and $m$-CAN selectivity ( $\sim 98 \%$, without the occurrence of over-hydrogenation), indicating no occurrence of deactivation for the catalyst during the reuse runs (Fig. 9(a)). According to the ICP-OES results in Table 1, no appreciable $\mathrm{Rh}$ leaching is detected. While the BET surface area of $\mathrm{Rh} @ \mathrm{Al}_{2} \mathrm{O}_{3} @ \mathrm{C}$ SAC slightly decreases from 219 to $180 \mathrm{~m}^{2} \cdot \mathrm{g}^{-1}$ (Table 1), possibly because of the deposition of carbonaceous
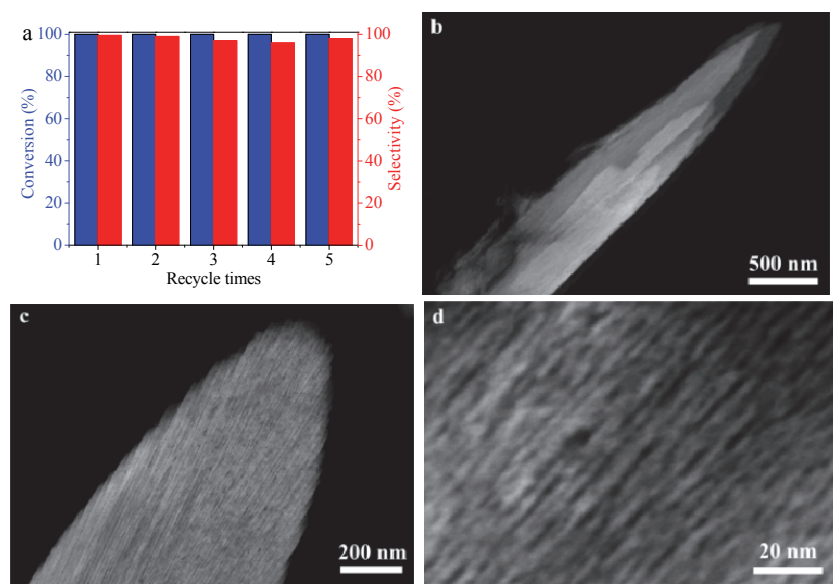

Fig. 9. (a) The recycling experiments of the $\mathrm{Rh} @ \mathrm{Al}_{2} \mathrm{O}_{3} @ \mathrm{C}$; (b-d) STEM images of the spent Rh@ $\mathrm{Al}_{2} \mathrm{O}_{3} @ \mathrm{C}$ after five consecutive runs. Reaction conditions: $T=313 \mathrm{~K}, P_{\mathrm{H} 2}=20 \mathrm{bar}, t=12 \mathrm{~h}, 30 \mathrm{mg}$ catalyst, $0.5 \mathrm{mmol}$ $m$-chloronitrobenzene, $2 \mathrm{~mL}$ toluene.

species derived from reactants or products. XRD pattern (Fig. S10) and STEM images (Fig. 9(b) and (c)) of the spent catalyst after five consecutive runs show negligible change of the

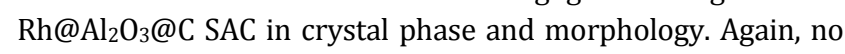
nanoparticles or nanoclusters observed in the high-resolution STEM images (Fig. 9(d)) corroborates the maintenance of Rh single-atom feature in $\mathrm{Rh}_{0} \mathrm{Al}_{2} \mathrm{O}_{3} @ \mathrm{C}$, indicating no occurrence of metal sintering for the SAC during catalysis. Therefore, an excellent stability is demonstrated for the $\mathrm{Rh}_{0} \mathrm{Al}_{2} \mathrm{O}_{3} @ \mathrm{C} \mathrm{SAC}$, consistent with the good stability of reported SACs for hydrogenation reactions in liquid phase and even under harsh conditions $[35,36]$.

\section{Conclusions}

In summary, we have shown an in-situ synthesis approach for the successful preparation of the $\mathrm{Rh@} \mathrm{Al}_{2} \mathrm{O}_{3} @ \mathrm{C}$ SAC material, via utilizing MIL-53 (Al) as scaffold. AC-HAADF-STEM and CO-IR reveal an exquisite structure of the $\mathrm{Rh} @ \mathrm{Al}_{2} \mathrm{O}_{3} @ \mathrm{C}$, containing atomically dispersed $\mathrm{Rh}$ sites onto $\mathrm{Al}_{2} \mathrm{O}_{3}$ confined by the amorphous carbon. A combined study of ${ }^{27} \mathrm{Al}$ MAS NMR and DFT calculation indicates the presence of the unsaturated $\mathrm{Al}^{\mathrm{V}}$ species in the $\mathrm{Rh} @ \mathrm{Al}_{2} \mathrm{O}_{3} @ \mathrm{C}$, serving as the anchoring sites for metal and essential for achieving the atomic dispersion of $\mathrm{Rh}$ atoms. This $\mathrm{Rh} @ \mathrm{Al}_{2} \mathrm{O}_{3} @ \mathrm{C}$ SAC has been evaluated and compared to the benchmark $\mathrm{Rh} / \gamma-\mathrm{Al}_{2} \mathrm{O}_{3}$ and $\mathrm{Rh} / \mathrm{C}$ nanocatalysts, for the selective hydrogenation of $m$-CNB to $m$-CAN at $313 \mathrm{~K}$ and 20 bar $\mathrm{H}_{2}$. The SAC affords an excellent turnover frequency of $2317 \mathrm{~mol}_{m-\mathrm{CNB}} \cdot \mathrm{mol}_{\mathrm{Rh}}{ }^{-1} \cdot \mathrm{h}^{-1}$, the highest value to date in heterogeneous catalyst systems for the hydrogenation of $m$-CNB under such mild conditions, together with a sustained selectivity to $m$-CAN ( 98\%) during five consecutive runs. The advanced catalytic performance of the $\mathrm{Rh} @ \mathrm{Al}_{2} \mathrm{O}_{3} @ \mathrm{C}$ is attributed to a proper modulation of electronic structure of hydrogenation metal by forming SAC, together with an enhanced accessibility of acid function sites. This work offers not only an efficient strategy for the fabrication of highly selective SAC via utilizing a metal-organic framework of MOF, 
but also presents a good example of proper modulation of different function sites, for achieving an enhanced and sustained chemoselectivity in catalysis.

\section{References}

[1] Peter F. Vogt and John J. Gerulis, Amines, Aromatic in Ullmann's Encyclopedia of Industrial Chemistry, Wiley, New Jersey, 2000.

[2] A. M. Alexander, J. S. J. Hargreaves, Chem. Soc. Rev., 2010, 39, 4388-4401.

[3] N. Ono, The nitro group in organic synthesis, Wiley, New Jersey, 2003.

[4] P. Lara, K. Philippot, Catal. Sci. Technol, 2014, 4, 2445-2465.

[5] D. Formenti, F. Ferretti, F. K. Scharnagl, M. Beller, Chem. Rev., 2019, 119, 2611-2680.

[6] J. Song, Z. F. Huang, L. Pan, K. Li, X. Zhang, L. Wang, J. J. Zou, Appl. Catal. B, 2018, 227, 386-408.

[7] Z. Wei, F. Shao, J. Wang, Chin. J. Catal., 2019, 40, 980-1002.

[8] R. A. Sheldon and H. van Bekkum, Fine Chemicals through Heterogeneous Catalysis, Wiley, New Jersey, 2008.

[9] G. Vilé, D. Albani, N. Almora-Barrios, N. López, J. Pérez-Ramírez, ChemCatChem, 2016, 8, 21-33.

[10] M. Pietrowski, Curr. Org. Synth., 2012, 9, 470-487.

[11] W. Shi, B. Zhang, Y. Lin, Q. Wang, Q. Zhang, D. S. Su, ACS Catal., 2016, 6, 7844-7854.

[12] M. Orlandi, D. Brenna, R. Harms, S. Jost, M. Benaglia, Org. Process Res. Dev., 2018, 22, 430-445.

[13] A. Corma, P. Serna, Science, 2006, 313, 332-334.

[14] J. Wu, L. Qi, H. You, A. Gross, J. Li, H. Yang, J. Am. Chem. Soc., 2012, 134, 11880-11883.

[15] L. Bu, N. Zhang, S. Guo, X. Zhang, J. Li, J. Yao, T. Wu, G. Lu, J. Y. Ma, D. Su, X. Huang, Science, 2016, 354, 1410-1414.
[16] C. Zhang, X. Wang, M. Li, Z. Zhang, Y. Wang, R. Si, F. Wang, Chin. J. Catal., 2016, 37, 1569-1577.

[17] H. Wei, X. Wei, X. Yang, G. Yin, A. Wang, X. Liu, Y. Huang, T. Zhang, Chin. J. Catal., 2015, 36, 160-167.

[18] J. Zhang, L. Wang, Y. Shao, Y. Wang, B. C. Gates, F. S. Xiao, Angew. Chem. Int. Ed., 2017, 56, 9747-9751.

[19] F. Cárdenas-Lizana, S. Gómez-Quero, A. Hugon, L. Delannoy, C. Louis, M. A. Keane, J. Catal., 2009, 262, 235-243.

[20] A. Wang, J. Li, T. Zhang, Nat. Rev. Chem., 2018, 2, 65-81.

[21] L. Zhang, M. Zhou, A. Wang, T. Zhang, Chem. Rev., 2020, 120, 683-733.

[22] L. Lin, S. Yao, R. Gao, X. Liang, Q. Yu, Y. Deng, J. Liu, M. Peng, Z. Jiang, S. Li, Y. W. Li, X. D. Wen, W. Zhou, D. Ma, Nat. Nanotechnol,, 2019, 14, 354-361.

[23] F. Chen, X. Jiang, L. Zhang, R. Lang, B. Qiao, Chin. J. Catal., 2018, 39, 893-898.

[24] H. Wei, X. Liu, A. Wang, L. Zhang, B. Qiao, X. Yang, Y. Huang, S. Miao, J. Liu, T. Zhang, Nat. Commun., 2014, 5, 5634.

[25] C. Wang, S. Mao, Z. Wang, Y. Chen, W. Yuan, Y. Ou, H. Zhang, Y. Gong, Y. Wang, B. Mei, Z. Jiang, Y. Wang, Chem, 2020, 6, 752-765.

[26] L. Shang, T. Bian, B. Zhang, D. Zhang, L. Z. Wu, C. H. Tung, Y. Yin, T. Zhang, Angew. Chem. Int. Ed., 2014, 53, 250-254.

[27] S. Mitchell, J.M. Thomas, J. Perez-Ramirez, Catal. Sci. Technol., 2017, 7, 4248-4249.

[28] G. Kresse, J. Furthmüller, Phys. Rev. B., 1996, 54, 11169-11186.

[29] J. P. Perdew, K. Burke, M. Ernzerhof, Phys. Rev. Lett., 1996, 77, 3865-3868.

[30] G. Kresse, D. Joubert, Phys. Rev. B: Condens. Matter Mater. Phys., 1999, 59, 1758-1775.

[31] S. Grimme, S. Ehrlich, L. Goerigk, J. Comput. Chem., 2011, 32, 1456-1465.

[32] G. Henkelman, B. P. Uberuaga, H. Jónsson, J. Chem. Phys., 2000,

\section{Graphical Abstract}

Chin. J. Catal., 2021, 42: 824-834 doi: 10.1016/S1872-2067(20)63697-X

MIL-53 (Al) derived single-atom Rh catalyst for the selective hydrogenation of $\boldsymbol{m}$-chloronitrobenzene into $\boldsymbol{m}$-chloroaniline

Weiyin Wang', Lu Lin†, Haifeng Qi, Wenxiu Cao, Zhi Li, Shaohua Chen, Xiaoxuan Zou*, Tiehong Chen, Nanfang Tang, Weiyu Song, Aiqin Wang, Wenhao Luo*

Xiangtan University; Dalian Institute of Chemical Physics, Chinese Academy of Sciences; University of Chinese Academy of Sciences; Jishou University; China University of Petroleum; Nankai University

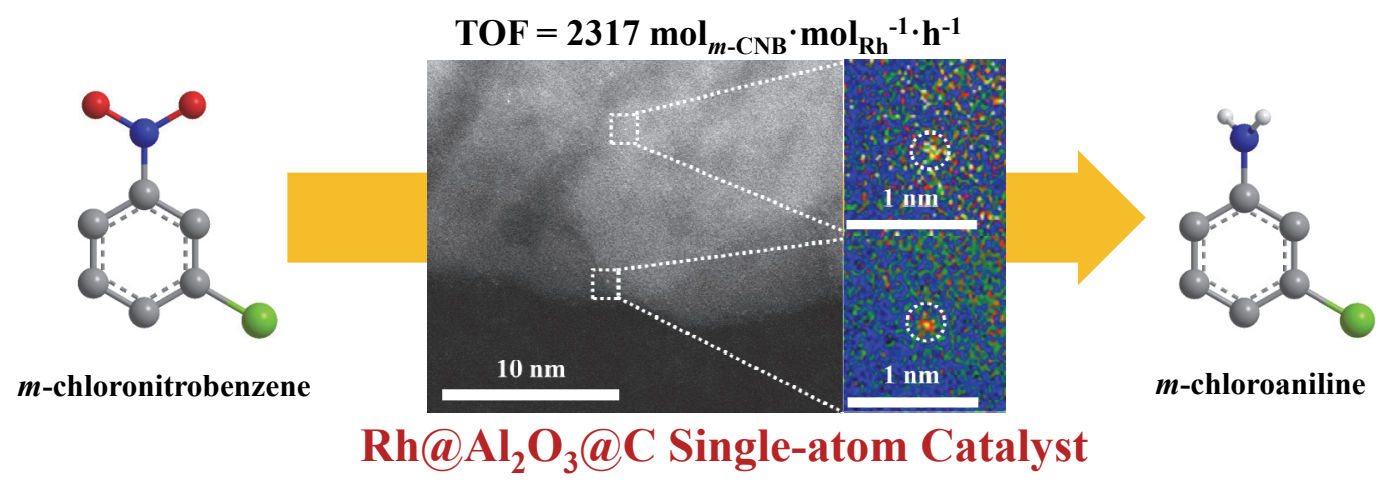

The Rh@Al $\mathrm{O}_{3} @ \mathrm{C}$ SAC, fabricated by utilizing a metal-organic framework of MIL-53 (Al), shows an excellent, sustained chemoselectivity for the hydrogenation of $m$-chloronitrobenzene. 
113, 9901-9904.

[33] S. Smidstrup, A. Pedersen, K. Stokbro, H. Jónsson, J. Chem. Phys., 2014, 140, 214106

[34] C. Serre, F. Millange, C. Thouvenot, M. Noguès, G. Marsolier, D. Louër, G. Férey, J. Am. Chem. Soc., 2002, 124, 13519-13526.

[35] W. Cao, W. Luo, H. Ge, Y. Su, A. Wang, T. Zhang, Green Chem., 2017, 19, 2201-2211.

[36] W. Cao, L. Lin, H. Qi, Q. He, Z. Wu, A. Wang, W. Luo, T. Zhang, J. Catal., 2019, 373, 161-172.

[37] D. Liu, F. Dai, Z. Tang, Y. Liu, C. Liu, Mater. Res. Bull., 2015, 65, 287-292.

[38] J. C. Matsubu, V. N. Yang, P. Christopher, J. Am. Chem. Soc., 2015, 137, 3076-3084.

[39] R. R. Cavanagh, J. T. Yates Jr., J. Chem. Phys., 1981, 74, 4150-4155.

[40] J. T. Y. Jr., T. M. Duncan, S. D. Worley, R. W. Vaughan, J. Chem. Phys., 1979, 70, 1219-1224.

[41] R. Lang, T. Li, D. Matsumura, S. Miao, Y. Ren, Y. T. Cui, Y. Tan, B. Qiao, L. Li, A. Wang, X. Wang, T. Zhang, Angew. Chem. Int. Ed., 2016, 55, 16054-16058.

[42] I. Eswaramoorthi, A. K. Dalai, Catal. Lett., 2009, 131, 203-212.

[43] F. Li, H. Ma, H. Zhang, W. Ying, D. Fang, C. R. Chim., 2014, 17, 1109-1115.

[44] H. Tang, Y. Su, Y. Guo, L. Zhang, T. Li, K. Zang, F. Liu, L. Li, J. Luo, B. Qiao, J. Wang, Chem. Sci., 2018, 9, 6679-6684.

[45] J. H. Kwak, J. Hu, D. Mei, C. W. Yi, D. H. Kim, C. H. F. Peden, L. F. Allard, J. Szanyi, Science, 2009, 325, 1670-1673.

[46] N. Tang, Y. Cong, Q. Shang, C. Wu, G. Xu, X. Wang, ACS Catal., 2017, 7, 5987-5991.

[47] Z. Zhang, Y. Zhu, H. Asakura, B. Zhang, J. Zhang, M. Zhou, Y. Han, T. Tanaka, A. Wang, T. Zhang, N. Yan, Nat. Commun., 2017, 8, 16100.

[48] M. Digne, P. Sautet, P. Raybaud, P. Euzen, H. Toulhoat, J. Catal. 2004, 226, 54-68.

[49] R. Wischert, P. Laurent, C. Copéret, F. Delbecq, P. Sautet, J. Am.
Chem. Soc. 2012, 134, 14430-14449.

[50] X. R. Shi, D. S. Sholl, J. Phys. Chem. C. 2012, 116, 10623-10631.

[51] M. C. Valero, P. Raybaud, P. Sautet, Phys. Rev. B., 2007, 75, 045427.

[52] G. Wienhöfer, I. Sorribes, A. Boddien, F. Westerhaus, K. Junge, H. Junge, R. Llusar, M. Beller, J. Am. Chem. Soc., 2011, 133, 12875-12879.

[53] F. Yang, M. Wang, W. Liu, B. Yang, Y. Wang, J. Luo, Y. Tang, L. Hou, Y. Li, Z. Li, Green Chem., 2019, 21, 704-711.

[54] W. C. Cheong, W. Yang, J. Zhang, Y. Li, D. Zhao, S. Liu, K. Wu, Q. Liu, C. Zhang, D. Wang, Q. Peng, C. Chen, Y. Li, ACS Appl. Mater. Interfaces, 2019, 11, 33819-33824.

[55] C. Xu, Q. Li, Q. Zhang, K. Li, H. Yin, S. Zhou, ACS Appl. Nano Mater, 2019, 2, 5086-5095.

[56] T. Schwob, R. Kempe, Angew. Chem. Int. Ed., 2016, 55, 15175-15179.

[57] P. Zhang, C. Yu, X. Fan, X. Wang, Z. Ling, Z. Wang, J. Qiu, Phys. Chem. Chem. Phys., 2015, 17, 145-150.

[58] C. Jiang, Z. Shang, X. Liang, ACS Catal., 2015, 5, 4814-4818.

[59] R. V. Jagadeesh, A. E. Surkus, H. Junge, M. M. Pohl, J. Radnik, J. Rabeah, H. Huan, V. Schünemann, A. Brückner, M. Beller, Science, 2013, 342, 1073-1076.

[60] F. A. Westerhaus, R. V. Jagadeesh, G. Wienhöfer, M. M. Pohl, J. Radnik, A. E. Surkus, J. Rabeah, K. Junge, H. Junge, M. Nielsen, A. Brückner, M. Beller, Nat. Chem., 2013, 5, 537-543.

[61] P. Luo, K. Xu, R. Zhang, L. Huang, J. Wang, W. Xing, J. Huang, Catal. Sci. Technol., 2012, 2, 301-304.

[62] H. Goksu, H. Sert, B. Kilbas, F. Sen, Curr. Org. Chem., 2017, 21, 794-820.

[63] J. Soria, A. Martinez-Arias, J. Fierro, J. Conesa, Vacuum, 1995, 46, 1201-1204.

[64] W. Liu, L. Zhang, W. Yan, X. Liu, X. Yang, S. Miao, W. Wang, A. Wang, T. Zhang, Chem. Sci., 2016, 7, 5758-5764.

\section{MIL-53 (AI)衍生的Rh单原子催化剂在间氯硝基苯选择性加氢制间氯苯胺 反应中的应用}

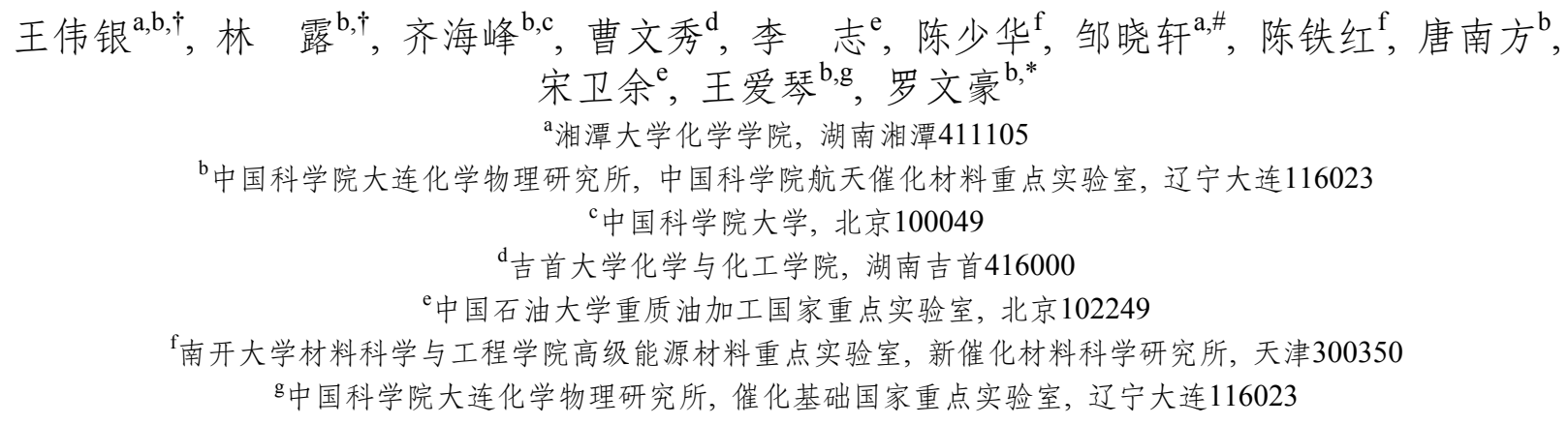


固体核磁共振与密度泛函理论计算的结果则进一步确定 $\mathrm{Al}_{2} \mathrm{O}_{3} @ \mathrm{C}$ 载体中存在的五配位的 $\mathrm{Al}$ 物种 $\left(\mathrm{Al}^{\mathrm{V}}\right)$ 是针定 $\mathrm{Rh}$ 单原子的 主要位点, $\mathrm{Al}^{\mathrm{V}}$ 的不饱和的配位结构可以有效地稳定 $\mathrm{Rh}$ 单原子, 对形成 $\mathrm{Rh}$ 位点的单原子分散至关重要. 在间氯硝基苯选择 性加氢制间氯苯胺反应中, 与等体积浸渍法制备的 $\mathrm{Rh} / \mathrm{C}$ 和 $\mathrm{Rh} / \gamma-\mathrm{Al}_{2} \mathrm{O}_{3}$ 纳米催化剂相比, $\mathrm{Rh} @ \mathrm{Al}_{2} \mathrm{O}_{3} @ \mathrm{C}$ 单原子催化剂表现出 优异催化性能:其在 $313 \mathrm{~K}$, 氢气压力为 $20 \mathrm{bar}$ 的温和条件下转换频率(TOF)高达 $2317 \mathrm{~mol}_{\mathrm{m}-\mathrm{CNB}} \cdot \mathrm{mol}_{\mathrm{Rh}}{ }^{-1} \cdot \mathrm{h}^{-1}$, 优于已报道的多 相金属催化剂, 是目前的最高值. 此外, 该催化剂展现出极佳的稳定性能, 经过五次循环后, 该催化剂对 $m$-CAN的选择性仍 旧保持在 $98 \%$ 左右. $\mathrm{Rh} @ \mathrm{Al}_{2} \mathrm{O}_{3} @ \mathrm{C}$ 单原子催化剂的优异催化性能源自于金属单原子结构的形成对于金属位点电子结构的 有效调节, 进而调控催化剂加氢性能并实现对加氢脱卤副反应的抑制; 与此同时, $\mathrm{Rh} @ \mathrm{Al}_{2} \mathrm{O}_{3} @ \mathrm{C}$ 催化剂增进了酸位点的可 及性, 从而促进了其串联步骤中包含的脱水反应的发生, 进而有效提高催化剂的反应活性.

关键词: 单原子催化剂; 铑; 金属有机骨架; 加氢反应; 化学选择性

收稿日期: 2020-05-08. 接受日期: 2020-07-07. 上网日期: 2020-09-22.

*通讯联系人. 电话: (0411) 84379738; 传真: (0411) 84685940; 电子信箱: w.luo@dicp.ac.cn

\#通讯联系人. 电子信箱: zouxiaoxuan@xtu.edu.cn

†共同第一作者.

基金来源: 中国科学院战略性先导科技专项(XDB17020100); 国家自然科学基金(21703238, 21690084, 21802134); 湖南省教育厅 优秀青年项目(19B463); 锛锌钒产业技术湖南省2011协同创新中心(MXF202001); 吉首大学人才启动基金(21).

本文的电子版全文由Elsevier出版社在ScienceDirect上出版(http://www.sciencedirect.com/science/journal/18722067). 